\title{
Effects of human alterations on the hydrodynamics and sediment transport in the Sacramento-San Joaquin Delta, California
}

\author{
MATHIEU D. MARINEAU \& SCOTT A. WRIGHT \\ US Geological Survey, 6000 J Street, Placer Hall, Sacramento, California, USA \\ mmarineau@usgs.gov
}

\begin{abstract}
The Sacramento-San Joaquin Delta, California, (Delta) has been significantly altered since the mid-nineteenth century. Many existing channels have been widened or deepened and new channels have been created for navigation and water conveyance. Tidal marshes have been drained and leveed to form islands that have subsided, some of which have permanently flooded. To understand how these alterations have affected hydrodynamics and sediment transport in the Delta, we analysed measurements from 27 sites, along with other spatial data, and previous literature. Results show that: (a) the permanent flooding of islands results in an increase in the shear velocity of channels downstream, (b) artificial widening and deepening of channels generally results in a decrease in shear velocity except when the channel is also located downstream of a flooded island, (c) $1.5 \mathrm{Mt} / \mathrm{year}$ of sediment was deposited in the Delta (19972010), and of this deposited sediment, $0.31 \mathrm{Mt} /$ year (21\%) was removed through dredging.
\end{abstract}

Key words delta, tidal channel, sediment transport, dredging, tidal prism, sediment budget, shear velocity

\section{INTRODUCTION}

Tidal channel hydrodynamics - velocity in particular - can play an important role in shaping ecosystem characteristics that drive biological processes. Changes in the hydraulic geometry (such as deepening of channels for navigation), and land-use changes (such as draining of marshes) in a tidal estuary can significantly alter the tidal channel hydrodynamics. Increased channel velocity and bed shear stress (or shear velocity) can result in increased sediment transport capacity, potential channel scour and erosion, increased suspended sediment, and coarsening of bedmaterial. Alternatively, decreased channel velocity and shear velocity can result in decreased sediment transport capacity, potential for aggradation, increased suspended-sediment flocculation, and reduced re-aeration (which can result in decreased dissolved oxygen; Smith, 1988). Changes in sediment transport can affect supply of material available for marsh accretion and restoration, downstream beach sand replenishment, and sand available for mining. Decreased shear stress, for example, may lead to more deposition in the Delta (beneficial for marshes, but may also increase the need for dredging of navigation channels). Here we explore some human-caused changes (in particular: man-made channels, artificially deepened and/or widened channels, and channels downstream of flooded islands) and attempt to quantify their effects on the hydrodynamics and sediment transport in the Sacramento-San Joaquin Delta, California, USA.

\section{DESCRIPTION OF STUDY AREA}

The Delta covers a triangular area generally defined by the confluence of the Sacramento and San Joaquin Rivers to the west, the Sacramento River reach approximately $35 \mathrm{~km}$ to the north, and the San Joaquin River reach approximately $40 \mathrm{~km}$ to the south. A map showing the study area and sample sites is presented in Fig. 1.

The hydrodynamics of the Delta are driven externally by climate, upstream dam operation, wind and tides, and internally by water diversions and a gate at the Delta Cross Channel. The Delta watershed has a drainage area of approximately $153000 \mathrm{~km}^{2}$, which includes most of the Central Valley. Discharge from the Sacramento River and San Joaquin River constitute 95\% of the inflow to the Delta. Average annual discharge in these rivers is $660 \mathrm{~m}^{3} / \mathrm{s}$ and $126 \mathrm{~m}^{3} / \mathrm{s}$; while the maximum recorded discharges are $3300 \mathrm{~m}^{3} / \mathrm{s}$ and $2240 \mathrm{~m}^{3} / \mathrm{s}$, respectively (USGS NWIS data, variously dated). Climate in the Central Valley is characterized by hot, dry summers and cool, wet winters but with highly variable annual precipitation (Mount, 1995). 


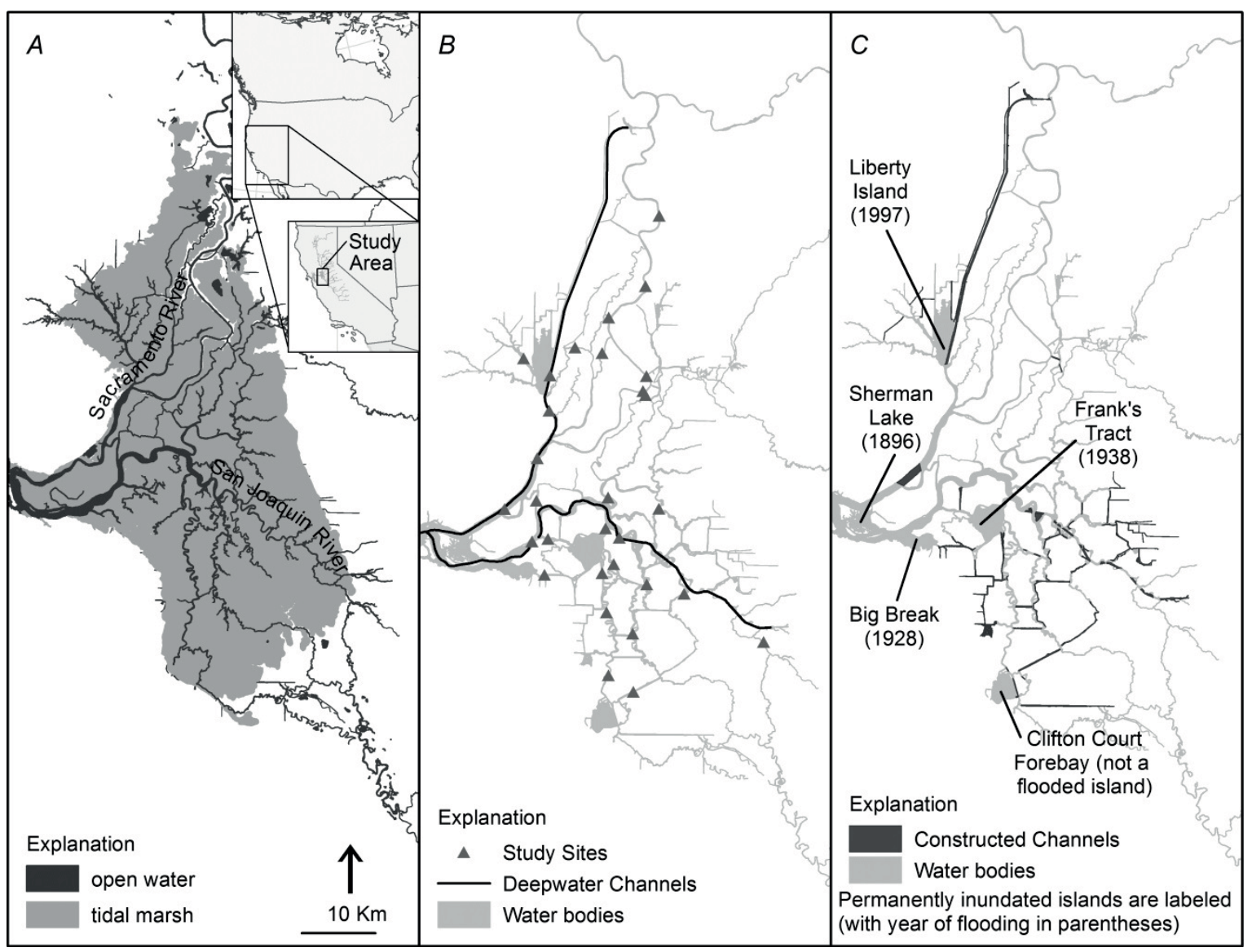

Fig. 1 Maps of study area showing: historical water bodies and tidal marsh (modified from Whipple et al., 2012) (A); present-day water bodies with deep-water shipping channels and study sites indicated (B); and present-day water bodies with man-made (i.e. constructed) channels indicated (C).

During high-flow events on the Sacramento River, water spills over a weir which serves to provide some flood protection to the City of Sacramento. Water spilling over this weir enters a flood-control bypass where it flows, often with a large suspended-sediment load, into the Delta at the northern end of now-flooded Liberty Island (Fig. 1C). The major tributary rivers are regulated by upstream dams which maintain constant freshwater discharge (for water exports through the Clifton Court Forebay, Fig. 1C) during the summer and, to some extent, reduce peak flows during storm events that usually occur during the winter and spring.

\section{HISTORICAL CHANGES TO THE DELTA}

When American pioneers first arrived in California in the nineteenth century, the Delta consisted primarily of tidal marsh with a complex network of tidal channels (Whipple et al. 2012) (Fig. 1A). By the end of the century, nearly all of these marsh areas were leveed, drained, and converted to farmland. Several man-made channels were constructed to facilitate transportation and water conveyance (Fig. 1C). These channels bisected the large tracts of drained marsh and formed "islands" in the Delta. Over the following century, most of these islands, which originally consisted of thick deposits of peat, had subsided, some by more than 9 metres (CADWR, 1995) (Fig. 3A). The subsidence has increased the hydrostatic pressure on the levees resulting in a greater potential for levee breaks and flooded islands (Ingebritsen et al., 2000). Every island in the Delta has flooded at least once, while many islands have flooded multiple times (CADWR, 1995). The four largest permanently-inundated islands are Sherman Lake, Big Break, Frank's Tract, and Liberty Island (Fig. 2C). Continued subsidence, sea-level rise, and seismic instability will likely result in additional levee breaks and flooded islands in the future (Mount and Twiss, 2005). 
Many of the levees were constructed using material dredged from the channel edge (Whipple et al., 2012), which resulted in artificially-widened channels. These levees have since been reinforced with riprap. The levee reinforcement prevents lateral channel adjustment and has largely fixed channel position and width for more than a century. In addition, two deep-water shipping channels were constructed through the Delta to accommodate large vessels (Fig. 1B). These channels were completed in 1963 and 1938, and later deepened in many areas in the early 1980s. The US Army Corps of Engineers (USACE) dredges these channels regularly to maintain their depth. All of these changes to the hydraulic geometry of the channels have the potential to impact the hydrodynamics and sediment transport dynamics in the Delta.

\section{METHODS}

\section{Data sources}

The USGS operates a network of streamgauges in the Delta to monitor stage, discharge, and other water quality constituents. These data were accessed through the USGS National Water Information System (NWIS) website (USGS NWIS, variously dated). Median bed-sediment particle size $\left(\mathrm{D}_{50}\right)$ and ninetieth-percentile particle size $\left(\mathrm{D}_{90}\right)$ were measured during 2011-2013 (USGS, unpublished data), bedform height and length were measured from several 100-130 m longitudinal profiles of depth at each site in 2012 (USGS, unpublished data). Representative channel cross-sections at each site were created by combining acoustic Doppler current profiler (ADCP) measurements (USGS, unpublished data) with above-water surface elevations derived from aerial LiDAR (CADWR, 2007). Annual volumes of material dredged from the shipping channels were obtained from USACE (2012) and, USACE-Sacramento District (Gary Kamai, pers. comm., 2013). Historical channel depth and width of a few select sites were derived from early nautical charts produced by Ringgold (1850).

\section{Shear velocity}

Shear velocity was calculated using the Keulegan (1938) equation, which relates depth-averaged water velocity to shear velocity by assuming a logarithmic velocity profile and negligible side-wall effects:

$$
\mathrm{U} / \mathrm{u}_{*}=(1 / \kappa) \ln \left(11 \mathrm{H} / \mathrm{k}_{\mathrm{s}}\right)
$$

where $U$ is the mean channel velocity, $u *$ is shear velocity, $\kappa$ is the von Kármán constant (0.407), $\mathrm{H}$ is average channel depth, and $\mathrm{k}_{\mathrm{s}}$ is the grain-roughness coefficient, computed here as $3 \mathrm{D}_{90}$ (as suggested by van Rijn, 1984). Shear velocity was computed at 15-minute time steps for 19972010. The critical shear stress, $\tau_{* c}$, was computed based on the relation presented by Brownlie (1981), using $\mathrm{D}_{50}$ as the representative particle size:

$$
\tau_{*_{\mathrm{c}}} /(\rho \mathrm{gRD})=0.22 \mathrm{R}_{\mathrm{ep}}^{-0.6}+0.06 \mathrm{e}^{\wedge}\left(-17.77 \mathrm{R}_{\mathrm{ep}}^{-0.6}\right)
$$

where $R_{\text {ep }}=(g R D)^{0.5} \mathrm{D} / v, R$ is the submerged specific weight of the sediment $(1.65), D_{50}$ is used for $\mathrm{D}, \rho$ is the density of water $\left(1000 \mathrm{~kg} / \mathrm{m}^{3}\right), \mathrm{g}$ is the acceleration due to the force of gravity $\left(9.81 \mathrm{~m} / \mathrm{s}^{2}\right)$, and $v$ is the kinematic viscosity of water $\left(1 \mathrm{E}-6 \mathrm{~m}^{2} / \mathrm{s}\right)$, and $\tau_{*_{c}}$ is converted to critical shear velocity, $\mathrm{u} *_{\mathrm{c}}$, by $\mathrm{u} *_{\mathrm{c}}=\left(\tau *_{\mathrm{c}} / \rho\right)^{0.5}$.

At each site, median $\mathrm{u} *$ was compared to $\mathrm{u}_{\mathrm{c}}$. In natural river and tidal systems, channels generally adjust their banks and beds through erosion or accretion until an equilibrium is reached (e.g. Friedrichs, 1995). In the Delta, channel width of most channels is fixed by reinforced levees. We hypothesize that median $\mathrm{u} *$ would be approximately equal to $\mathrm{u} *_{\mathrm{c}}$ in channels which are at or near equilibrium, but will be noticeably higher (or lower) following a channel alteration or major change in the flow regime (such as the flooding of an upstream island).

\section{Sediment transport}

Measurements of suspended-sediment load entering the Delta (1997-2010) from the Sacramento (Freeport gauge) and San Joaquin (Vernalis gauge) rivers were downloaded from NWIS (USGS 
NWIS, variously dated). Average annual suspended-sediment load estimates for the Yolo Bypass and the small east-side tributaries were from Wright and Schoellhamer (2005). Average annual estimates of suspended-sediment load exiting the Delta (1997-2012, at Mallard Island) were from McKee et al. (2013).

Bedload is not currently measured at any streamgauge in the Delta. In the absence of bedload measurements, bedload transport rates were calculated at 15-minute time steps using the procedure developed by van Rijn (1984) with the hydrodynamic, bed-sediment, and bed-form information described above. One caveat is that bedforms were only measured in 2012 and their dimensions were assumed static for the period of study. Bedforms, however, have been observed to change with flow (e.g. Dinehart, 2002).

The sum of the calculated bedload and the measured suspended load was used to estimate total sediment load entering and exiting the Delta on an annual basis.

\section{Tidal prism}

Tidal prism is defined as the average volume of water which flows into or out of a defined area due to tidal forces. A common method to calculate tidal prism (typically used for bays) is the product of the surface area of the water body and the tidal range (difference between Mean Higher High Water and Mean Lower Low Water). Alternatively, the tidal prism can be calculated by numerically integrating the tidal discharge, $Q^{\prime}$, using:

$$
\mathrm{Q}^{\prime}=\mathrm{Q}-\langle\mathrm{Q}\rangle
$$

where $\mathrm{Q}$ is the measured streamflow discharge time series, and $\langle\mathrm{Q}\rangle$ is the tidally-filtered discharge time series. Tidal prism is then determined by computing the mean of the absolute values of Q' and dividing by one-half of the tidal period (half, because the tidal period encompasses both a flood and an ebb tide):

$$
\Omega=\left|\bar{Q}^{\prime}\right| \mathrm{T} / 2
$$

where $\Omega$ is the volume of the tidal prism, and $\mathrm{T}$ is the tidal period (12 hours and 25 minutes for semi-diurnal tides on the western coast of the United States).

In this study, we address the question of how shear velocity in a channel is affected by the flooding of an upstream island. Shear velocity in most Delta channels is affected by both tidal and fluvial discharge. Therefore, we define the effective tidal prism, $\Omega_{\mathrm{e}}$, as the average volume of the ebb and flood tide discharge, including the fluvial contribution, during a tidal period and is computed by:

$$
\Omega_{\mathrm{e}}=|\overline{\mathrm{Q}}| \mathrm{T} / 2
$$

where $\Omega_{\mathrm{e}}$ is the effective tidal prism, and $|\overline{\mathrm{Q}}|$ is the mean of the absolute values of Q. Next we relate $\Omega_{\mathrm{e}}$ to $\mathrm{u} *$. Since $\mathrm{U}$, in equation (1), is equivalent to $\overline{\mathrm{Q}} / \overline{\mathrm{A}}$ and equation (5) can be rewritten in terms of $\Omega_{\mathrm{e}}$ such that $2 \Omega_{\mathrm{e}} / \mathrm{T}=|\overline{\mathrm{Q}}|$, then equation (1) can be rewritten as:

$$
\left[\left(2 \Omega_{\mathrm{e}}\right) /(\mathrm{TA})\right] / \mathrm{u}_{*}=(1 / \kappa) \ln \left(11 \mathrm{H} / \mathrm{k}_{\mathrm{s}}\right)
$$

Assuming $\mathrm{H}$ and $\mathrm{k}_{\mathrm{s}}$ do not differ before and after the flooding of an upstream island, we can compute a new value for $\mathrm{u} *$ (without the flooded island) and compare this to the value representing present-day conditions. In this case, the right-hand side of equation (6) is the same both with and without the flooded island, therefore:

$$
\left.\left[\left(2 \Omega_{\mathrm{e}(\mathrm{w} / \text { island })}\right) /(\mathrm{TA})\right] / \mathrm{u}_{* \text { (w/island })}=\left[\left(2 \Omega_{\mathrm{e}(\mathrm{w} / \mathrm{o} \text { island })}\right) /(\mathrm{TA})\right] / \mathrm{u}_{*} \text { (w/o island }\right)
$$

where the left-hand side includes $\Omega_{\mathrm{e}}$ and $\mathrm{u} *$ with the flooded island and the right-hand side includes $\Omega_{\mathrm{e}}$ and $\mathrm{u} *$ without the flooded island. $\Omega_{\mathrm{e}}$ (w/o island) was calculated by subtracting the tidal prism of the flooded island (Table 1) from the $\Omega_{\mathrm{e}}$ at the site (calculated using equation (5)). Equation (7) can be simplified and rewritten to solve for $\mathrm{u} *$ without the island, $\mathrm{u} *(\mathrm{w} / \mathrm{o}$ island):

$$
\mathrm{u}_{*(\mathrm{w} / \mathrm{o} \text { island })}=\left(\Omega_{\mathrm{e}(\mathrm{w} / \mathrm{o} \text { island })} / \Omega_{\mathrm{e}(\mathrm{w} / \text { island })}\right) \cdot \mathrm{u}_{*(\mathrm{w} / \text { island })}
$$


While the water velocity at any time in the tidal wave is dependent on the bathymetry of the upstream inundated area, this method allows for a rough approximation of the shear velocity at a site if the upstream flooded island did not exist and assuming channel geometry does not change.

We compute shear velocity at four sites in the Delta and compare those results to present-day conditions under three scenarios: (a) 1850, historical conditions, (b) present-day channel crosssectional area but without the upstream flooded island, and (c), historical channel cross-sectional area with the flooded island. This allowed for a simple comparison of the magnitude that channel or flow alteration had on the change in shear velocity.

\section{RESULTS}

\section{Shear velocity vs Critical shear velocity}

Median absolute shear velocity $\left(\mathrm{u}_{*}\right)$ was computed at 27 sites in the Delta and compared to $\mathrm{u}_{\mathrm{c}}$ calculated from $\mathrm{D}_{50}$ sampled at that site (Fig. 2A). Minimum and maximum values of $\mathrm{u} *$ were 0.46 and $2.1 \mathrm{~cm} / \mathrm{s}$, respectively, while the average $\mathrm{u} *$ for all sites was $1.2 \mathrm{~cm} / \mathrm{s}$.

Sites which have incurred major channel alterations or were downstream of flooded islands are identified (Fig. 2A and 2B). Four of the five sites downstream of flooded islands generally had $\mathrm{u} *$ which exceeded $\mathrm{u}_{*_{\mathrm{c}}}$ even though two of those sites are located within artificially-deepened ship channels. The $u_{*}$ at all sites which have been artificially widened were below $u_{*_{c}}$. The $u_{*}$ in manmade channels and other (less-altered) channels was generally equal to or less than $\mathrm{u}_{{ }_{\mathrm{c}}}$. The map of the Delta in Fig. 3B shows the ratio of $\mathrm{u} * / \mathrm{u} *_{\mathrm{c}}$ for all 27 study sites.
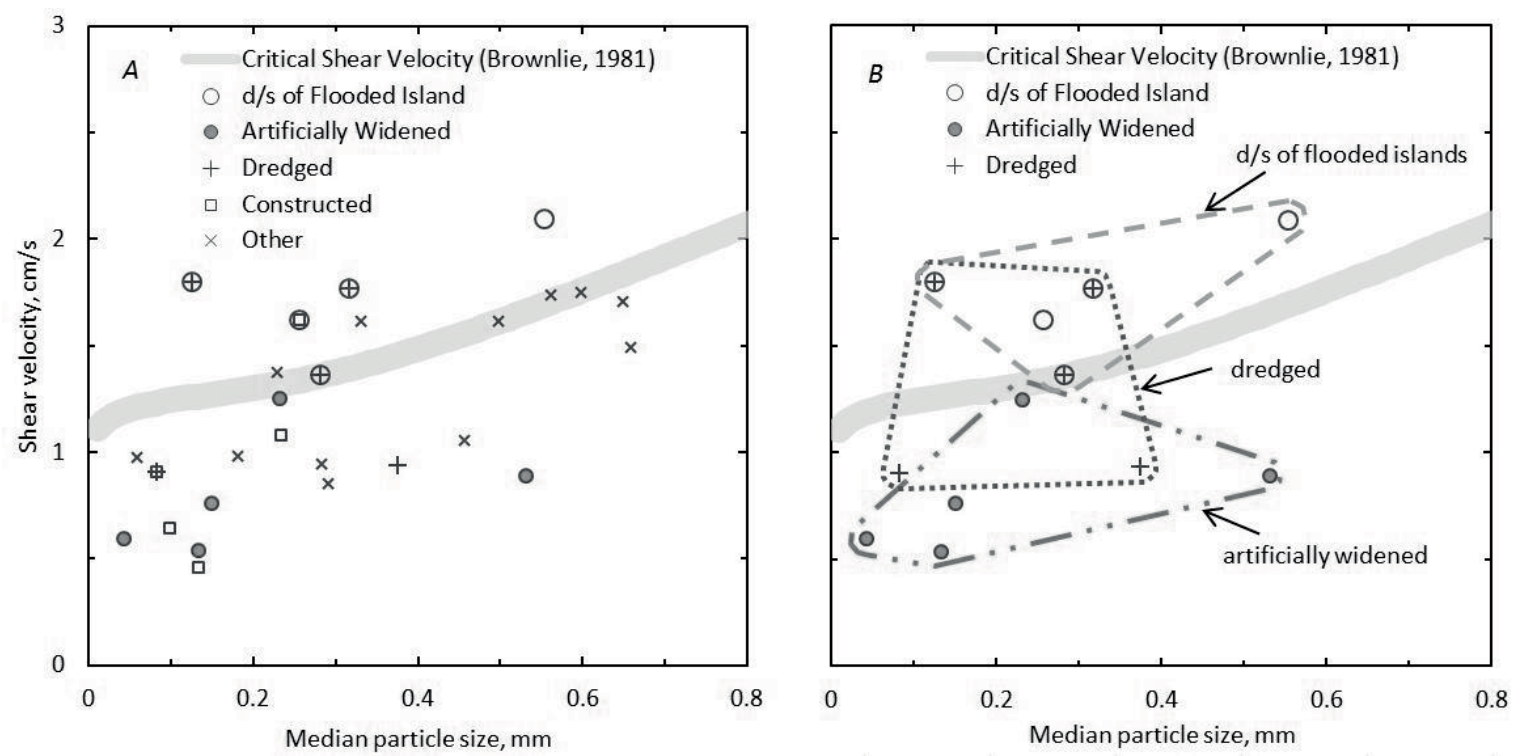

Fig. 2 Median shear velocity calculated for each study site in the Delta with channel type indicated (A), and with groups of selected channel types outlined (B). Note: some sites are characterized by two channel types.

\section{Tidal prism}

We compared two methods for computing tidal prism, the area-tidal range method and the numerical integration method (equations (3) and (4)) at one site in the Delta which has a welldefined boundary and an active streamgauge recording streamflow discharge at the outlet (the upper portion of the Sacramento Deep Water Ship Channel). The area is $7.27 \mathrm{~km}^{2}$ and the tidal range was $1.19 \mathrm{~m}$ at the gauge resulting in a tidal prism of $8.63 \mathrm{Mm}^{3}$ using the first method and a tidal prism of $8.11 \mathrm{Mm}^{3}$ using the second method (a difference of 6\%). At this particular site, the tidal forces are likely dampened by friction as they travel up the 12-km waterway. The application 
of a single tidal-range value, which was calculated at the downstream end, over the entire waterway may result in an overestimation of the tidal prism using the area-tidal range method.

Tidal prism was calculated using the area-tidal range method for Frank's Tract, Liberty Island, and the upper (man-made) portion of the Sacramento Deep Water Shipping channel (Table 1). The shear velocity at four sites downstream of flooded islands was compared to the estimated shear velocity without the influence of the flooded islands (Table 2).

Values for $\mathrm{u} *$ and $\mathrm{u} * \mathrm{u} *_{\mathrm{c}}$ ratio for Scenario 1 and 2 (Table 2) provide some indication as to the magnitude that these changes (dredging and upstream island flooding) have on shear velocity. When analysing each change alone, the flooding of the upstream island resulted in an average increase in shear velocity by $109 \%$ (over historical conditions) while the construction of the deepwater channel resulted in an average decrease of about $35 \%$.

Table 1 Summary calculations of open water area, marsh surface, and tidal prism for the Delta [historical period, three areas of interest, and present day (2014)], and change from historical to 2014.

\begin{tabular}{|c|c|c|c|c|c|c|}
\hline & \multirow{2}{*}{$\begin{array}{l}\text { Historical } \\
\text { (pre 1850`s) } \\
\text { Entire Delta }^{\mathrm{a}}\end{array}$} & \multicolumn{4}{|c|}{ Present-day (2014) } & \multirow{2}{*}{$\begin{array}{l}\text { Delta-wide } \\
\text { change }(1850 \\
\text { to } 2014)\end{array}$} \\
\hline & & $\begin{array}{l}\text { Franks } \\
\text { Tract }^{\mathrm{b}}\end{array}$ & $\begin{array}{l}\text { Liberty } \\
\text { Island }^{b}\end{array}$ & $\begin{array}{l}\text { Sacramento Deep- } \\
\text { water channel }^{\mathrm{c}}\end{array}$ & $\begin{array}{l}\text { Entire } \\
\text { Delta }^{\mathrm{d}}\end{array}$ & \\
\hline Tidal Prism & $220 \mathrm{Mm}^{3}$ & $12.7 \mathrm{Mm}^{3}$ & $14.9 \mathrm{Mm}^{3}$ & $8.11 \mathrm{Mm}^{3}$ & $230 \mathrm{Mm}^{3}$ & $+5 \%$ \\
\hline \multicolumn{7}{|c|}{ (a) Source: Gilbert (1917) } \\
\hline \multicolumn{7}{|c|}{ (b) Tidal prism calculated using area-tidal range method } \\
\hline \multicolumn{7}{|c|}{ (c) Tidal prism for the upper 12-km of the deep-water ship channel (Fig 3A) calculated e } \\
\hline \multicolumn{7}{|c|}{$\begin{array}{l}\text { Source: Present-day Delta-wide tid } \\
\text { flooded in 1997) }\end{array}$} \\
\hline
\end{tabular}

Table 2 Measured median discharge, and calculated shear velocity compared to estimated median discharge and shear velocity assuming the absence of an upstream flooded island; calculated critical shear velocity for these sites is also shown

\begin{tabular}{|c|c|c|c|c|c|c|c|c|c|c|c|c|c|}
\hline \multirow[b]{2}{*}{ Site } & \multicolumn{4}{|c|}{$\begin{array}{c}\text { Present-day } \\
2014\end{array}$} & \multicolumn{4}{|c|}{$\begin{array}{l}\text { Historical } \\
1850^{\mathrm{d}}\end{array}$} & \multicolumn{2}{|c|}{$\begin{array}{c}\text { Scenario } 1 \\
\text { (no flooded } \\
\text { island) }{ }^{\mathrm{e}}\end{array}$} & \multicolumn{2}{|c|}{$\begin{array}{l}\text { Scenario } 2 \\
\text { (no dredged } \\
\text { channel) }{ }^{\mathrm{f}}\end{array}$} & \multirow[b]{2}{*}{$\begin{array}{c}\mathrm{u} *_{\mathrm{c}} \\
\mathrm{cm} / \mathrm{s}\end{array}$} \\
\hline & $\begin{array}{c}\Omega_{\mathrm{e}} \\
\mathrm{Mm}^{3}\end{array}$ & $\begin{array}{c}\mathrm{A} \\
\mathrm{m}^{3}\end{array}$ & $\begin{array}{c}\mathrm{u} * \\
\mathrm{~cm} / \mathrm{s}\end{array}$ & $\begin{array}{l}\mathrm{U} * / \mathrm{u} * \mathrm{c} \\
\text { ratio }\end{array}$ & $\begin{array}{c}\Omega_{\mathrm{e}} \\
\mathrm{Mm}^{3}\end{array}$ & $\begin{array}{c}\mathrm{A} \\
\mathrm{m}^{3}\end{array}$ & $\begin{array}{c}\mathrm{u}^{*} \\
\mathrm{~cm} / \mathrm{s} \\
\end{array}$ & $\begin{array}{l}\mathrm{U} * / \mathrm{u} * \mathrm{c} \\
\text { ratio }\end{array}$ & $\begin{array}{c}\mathrm{u}^{*} \\
\mathrm{~cm} / \mathrm{s}\end{array}$ & $\begin{array}{l}\mathrm{u} * / \mathrm{u} * \mathrm{c} \\
\text { ratio }\end{array}$ & $\begin{array}{c}\mathrm{u} * \\
\mathrm{~cm} / \mathrm{s}\end{array}$ & $\begin{array}{l}\mathrm{u} * / \mathrm{u} * \mathrm{c} \\
\text { ratio }\end{array}$ & \\
\hline $\mathrm{RYI}^{\mathrm{a}, \mathrm{c}}$ & 35.1 & 3163 & 1.80 & 1.43 & 12.1 & 1400 & 1.36 & 1.08 & 0.49 & 0.39 & 3.94 & 3.13 & 1.26 \\
\hline $\mathrm{SRV}^{\mathrm{a}, \mathrm{c}}$ & 44.1 & 5660 & 1.36 & 1.00 & 21.1 & 2200 & 1.70 & 1.25 & 0.65 & 0.48 & 3.56 & 2.62 & 1.36 \\
\hline $\mathrm{FAL}^{\mathrm{b}}$ & 21.9 & 1992 & 2.09 & 1.23 & 9.2 & unk & unk & unk & 0.88 & 0.52 & $\mathrm{n} / \mathrm{a}$ & $\mathrm{n} / \mathrm{a}$ & 1.69 \\
\hline $\mathrm{SJJ}^{\mathrm{b}, \mathrm{c}}$ & 61.3 & 6005 & 1.76 & 1.27 & 48.6 & 5300 & 1.68 & 1.21 & 1.40 & 1.00 & 2.12 & 1.53 & 1.39 \\
\hline
\end{tabular}

(a) RYI, SRV downstream of Liberty Island and upper 12-km of Sacramento Deep Water Ship Channel;

(b) FAL, SJJ downstream of Frank's Tract

(c) Site located in existing deep-water ship channel

(d) Source: depths were derived from Ringgold (1850) navigation charts; historical data not available for FAL site

(e) Assumes present-day channel cross-sectional area, A, but without an upstream flooded island; calculated using equation (8)

(f) Assumes historical channel cross-sectional area, A, with an upstream flooded island; calculated using equation (6)

\section{Sediment transport}

We estimate that in the years 1997-2010, an average 2.3 million metric tons (Mt) of sediment was transported to the Delta and $0.83 \mathrm{Mt}$ was transported from the Delta annually. On average, $64 \%$ (or 1.5 Mt/year) of the sediment transported to the Delta was deposited there. Of the sediment transported to the Delta, we estimate that less than $2 \%$ was through bedload transport.

The average annual volume of sediment dredged from the deep-water shipping channels was $0.28 \mathrm{Mm}^{3}$, which equates to an average annual mass of $0.31 \mathrm{Mt}$ with density of $1112 \mathrm{~kg} / \mathrm{m}^{3}$ computed from the equation of Lara and Pemberton (1963) using bed particle size data from dredged areas. Thus, of the $1.5 \mathrm{Mt}$ of sediment deposited in the Delta annually, approximately $20 \%$ was removed through dredging during the study period (1997-2010). 


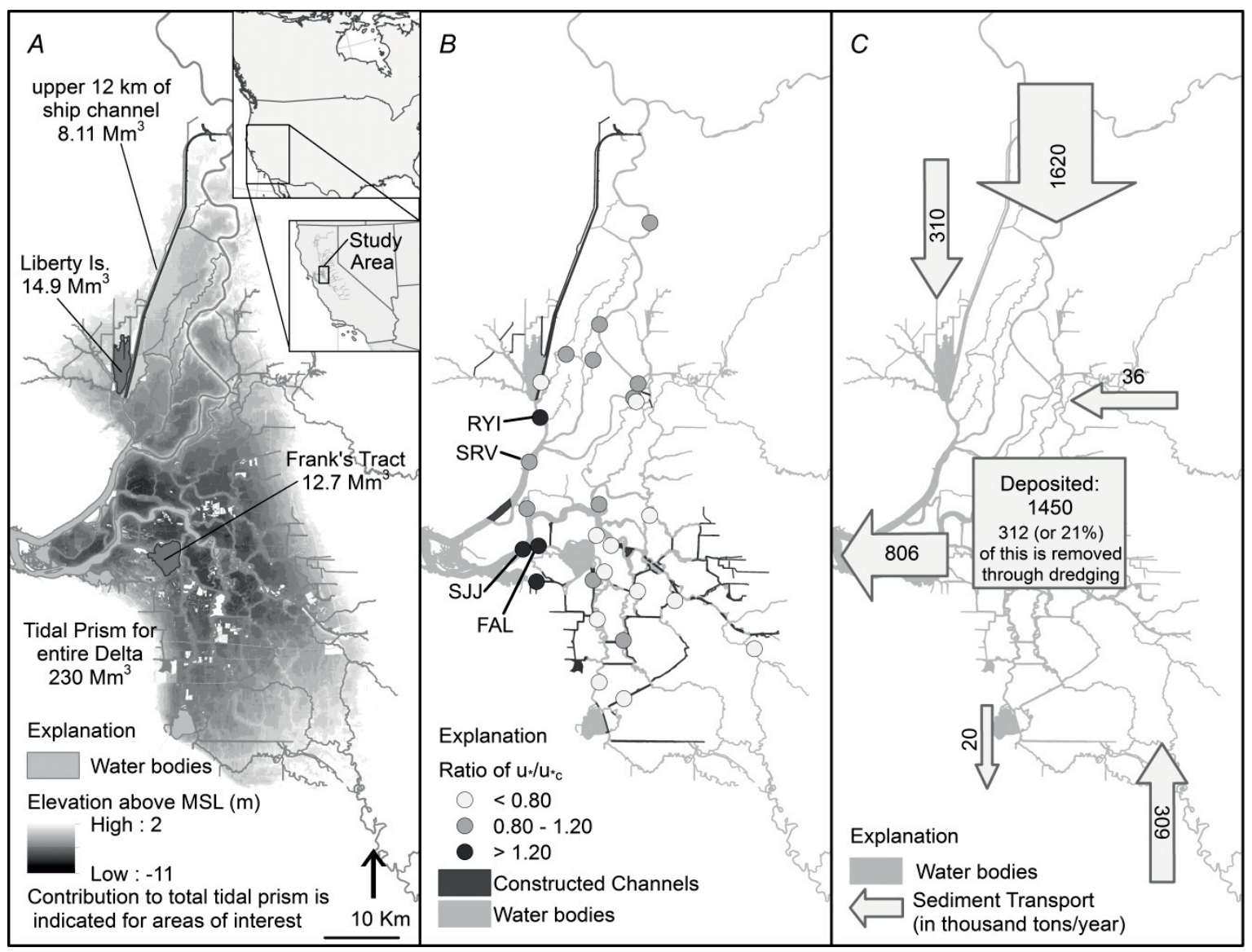

Fig. 3 Maps showing: tidal prism of areas of interest, total tidal prism of Delta and elevation of adjacent land above/below mean sea level (MSL), in metres (A); ratio of average shear velocity to critical shear velocity at each site, constructed water channels are also indicated (B); average annual sediment transport to and from the Delta 1997-2010 (C).

\section{DISCUSSION}

Comparison calculations (Table 2) and other results (Fig. 2) show that the additional tidal prism caused by a flooded island results in an increase in the shear velocity of channels downstream. The effect of the increase, however, is partially mitigated at sites co-located with deep-water shipping channels (where the enlarged cross-sectional area can better accommodate the additional tidal prism). An additional factor in this increased shear velocity is anthropogenic bank protection, which prevents channel adjustment toward a new state of equilibrium. Increased shear velocity results in greater sediment transport capacity in these areas. Many existing islands in the Delta are below sea-level (Fig. 3A) so it is possible that future islands will become permanently inundated (see also Mount and Twiss, 2005), further altering the tidal prism and increasing mean channel velocity and bed shear velocity.

Of the channels which are artificially widened and dredged (except those downstream of flooded islands), the median $\mathrm{u} *$ is much lower than $\mathrm{u}_{\mathrm{c}}$. The average $\mathrm{u} * \mathbf{u} *_{\mathrm{c}}$ ratio of these channels was 0.60. Annual maintenance dredging of the deep-water shipping channels is one obvious mechanism preventing substantial accretion (and thus preventing the channel from adjusting towards equilibrium), as is an overall limited supply of sediment. Sediment supply in the basin has declined over the last 60 years (Wright and Schoellhamer, 2004), so it is likely that these channels will remain low-velocity channels for many years to come.

Low channel velocity and shear velocity associated with deep-water shipping channels and artificially-widened channels may also increase their vulnerability to invasion by exotic aquatic macrophytes. For example, water hyacinth (Eichhornia crassipes) has been frequently observed by 
the authors in the channels in the southern Delta (which have lower channel velocity than most other channels (Fig. 3B)) but not in the channels in the northern parts of the Delta (we could not find any published information which documents the locations or extent of Hyacinth in the Delta). Also, Santos et al. (2010) estimate that $20-60 \%$ of the channel area in this region is covered with Brazilian waterweed (Egeria densa). However, a direct link between channel alterations and exotic invasive species in the Delta has not been established.

On average, approximately $1.5 \mathrm{Mt} /$ year of sediment was deposited in the Delta from 19972010. This is of the same order of magnitude as estimates by CADWR (1983) of 0.7-1.6 Mt and Wright and Schoellhamer (2005) of 1.1 Mt (suspended sediment only for 2001-2003). Of the $1.5 \mathrm{Mt} /$ year of sediment deposited, we estimate that $21 \%$ of this was removed through maintenance dredging. The dredged portions of the shipping channels account for only $7 \%$ of the channels in the Delta (by area); thus, they are preferential depositional areas.

\section{REFERENCES}

Brownlie, W. (1981) Prediction of flow depth and sediment discharge in open channels, Report No. KH-R-43A, Keck Laboratory of Hydraulics and Water Resources, California Institute of Technology, Pasadena, California.

CADWR (1983) Sedimentation and Scour, Delta Impacts Staff Paper, Interim Report, State of California Department of Water Resources Central District.

CADWR (1995) Sacramento San Joaquin Delta Atlas, California Department of Water Resources, Sacramento, California.

CADWR (2007) Delta area DEM based on 2007 LiDAR mapping by CADWR http://projects.atlas.ca.gov/projects/deltadata1/

Dinehart, R. L. (2002) Bedform movement recorded by sequential single-beam surveys in tidal rivers, J. Hydrol. 258(1-4), 25-39, doi:10.1016/S0022-1694(01)00558-3.

Friedrichs, C. T. (1995) Stability shear stress and equilibrium cross-sectional geometry of sheltered tidal channels. J. Coast. Res. 11(4), 1062-1074.

Gilbert, G.K. (1917) Hydraulic-mining debris in the Sierra Nevada. US Geol. Survey Professional Paper 105. p 154.

Ingebritsen, S. E., et al. (2000) Delta Subsidence in California. The Sinking Heart of the State. US Geol. Survey Fact Sheet 00500 .

Keulegan, G. H. (1938) Laws of turbulent flow in open channels. J. Res. Natl. Bureau of Standards (1934), 21(6), 707-741, doi:10.6028/jres.021.039.

Lara, J. M. \& Pemberton, E. L. (1963) Initial unit weight of deposited sediments. Paper No. 82. Proceedings of the Federal Interagency Sedimentation Conference, Miscellaneous Publication No. 970, 818-845. Agricultural Research Service.

McKee, L. J., et al. (2013) Comparison of sediment supply to San Francisco Bay from watersheds draining the Bay Area and the Central Valley of California. Marine Geology. 345(1), 47-62.

Mount, J. F. (1995) California rivers and streams: the conflict between fluvial process and land use. University of California Press, Berkeley and Los Angeles, CA.

Mount, J. \& Twiss, R. (2005) Subsidence, sea level rise, and seismicity in the Sacramento-San Joaquin Delta, San Francisco Estuary Watershed 3(1), 1-18.

Ringgold C. (1850) Chart of the Sacramento River. Courtesy of David Rumsey Map Collection, available online: http://www.davidrumsey.com/

Santos, M. J., Anderson, L. W. \& Ustin, S. L. (2010) Effects of invasive species on plant communities: an example using submersed aquatic plants at the regional scale. Biological Invasions, 13(2), 443-457, doi 10.1007/s10530-010-9840-6.

Smith, D. J. (1988) Effects of the Stockton Ship Channel Deepening on Dissolved Oxygen near the Port of Stockton, California, Lafayette, CA. US Army Corps of Engineers, Sacramento, CA.

USACE (2012) Dredged Material Management Plan for the Sacramento River Deep Water Ship Channel (SRDWSC) Deepening Project. Final Report, December 2012, Sacramento District U.S. Army Corps of Engineers.

USGS NWIS, streamgage data, variously dated, Available from: http://waterdata.usgs.gov/ca/nwis/rt (accessed: 2013-2014).

Van Rijn, L. (1984) Sediment transport, part I: bed load transport. J. Hydraul. Eng. 110(10), 1431-1456.

Whipple, A., et al. (2012) Sacramento-San Joaquin Delta Historical Ecology Investigation : Exploring Pattern and Process. San Francisco Estuary Institute.

Wright, S. A. \& Schoellhamer, D. H. (2004) Trends in the sediment yield of the Sacramento River, California, 1957-2001. San Fr. Estuary Watershed, 2(2).

Wright, S. A. \& Schoellhamer, D. H. (2005) Estimating sediment budgets at the interface between rivers and estuaries with application to the Sacramento-San Joaquin River Delta. Water Resour. Res. 41(9), 1-17, doi:10.1029/2004WR003753. 